\title{
Influence of Slow-rate Freezing and Vitrification on Mouse Embryos
}

\author{
R. HREDZÁK ${ }^{1}$, A. OSTRÓ ${ }^{1}$, I. MARAČEK ${ }^{2}$, J. KAČMÁRIK ${ }^{3}$, V. ŽDILOVÁ ${ }^{1}$, J. VESELÁ 4 \\ ${ }^{1}$ Centre of Assisted Reproduction, 2nd Gynaecological-obstetrical Clinic, Faculty Hospital of L. Pasteur \\ and Medical Faculty, University of P. J. Šafárik, Košice, Slovak Republic \\ 2 Department of Anatomy, Histology and Physiology, \\ ${ }^{3}$ Clinic of Obstetrics, Gynaecology and Andrology, University of Veterinary Medicine, Košice, \\ Slovak Republic \\ ${ }^{4}$ Institute of Farm Animal Physiology, Slovak Academy of Sciences, Košice, Slovak Republic \\ Received February 11, 2004 \\ Accepted March 3, 2005
}

\begin{abstract}
Hredzák, R., A. Ostró, I. Maraček, J. Kačmárik, V. Ždilová, J. Veselá: Influence of Slow-rate Freezing and Vitrification on Mouse Embryos. Acta Vet. Brno 2005, 74: 23-27.

The aim of the study was to compare the effect of two different methods of embryo freezing (slow-rate freezing employing programmable freezing equipment and ultra-rapid freezing by vitrification) on developmental capacity of two-cell mouse embryos on the basis of their development to blastocyst stage and implantation rate of blastocysts. Two-cell embryos were obtained from superovulated female mice and divided to three groups. The first group of embryos was frozen by the slow controlled-rate method using a programmable freezing equipment with propanediol as a cryoprotectant. Embryos from the second group were vitrified employing ethylene glycol as a cryoprotectant. The third group of embryos was cultivated in vitro without cryopreservation in a cultivation medium in an atmosphere of $95 \%$ air and $5 \% \mathrm{CO}_{2}$. After thawing, the embryos from the first two groups were cultivated in vitro under conditions identical to those used for fresh embryos. The blastocysts that developed in vitro from embryos of all three groups were transferred to uteri of pseudo-gravid female mice to determine their implantation capacity. The percentage of vitrified embryos that developed into blastocysts was significantly lower than that of the fresh and slow-rate frozen embryos. The morphological appearance of embryos from all three groups was the same. The implantation rate of blastocysts that developed from vitrified embryos was significantly lower compared to the fresh and slow-rate frozen embryos. The results obtained indicate that freezing of embryos affects negatively their further development the negative effect of vitrification being more detrimental. As a "universal" vitrification protocol has not yet been defined, additional studies are needed to achieve its optimisation.
\end{abstract}

Cryopreservation, cryoprotectant, implantation, slow-rate freezing, vitrification

Cryopreservation has become an inseparable part of methods of assisted reproduction. It offers the potential advantages of reducing the risk of multiple births while increasing the number of pregnancies per retrieval. The first successful freezing of mouse embryos was published in 1972 and since then many authors reported successful freezing and thawing of various mammal embryos including human ones.

The success of freezing depends partially on the freezing and thawing techniques. The traditional method of freezing, the so-called slow controlled-rate freezing, requires the use of a programmable freezing equipment which can ensure controlled gradual temperature decline. This method is cost- and time-demanding. More effective, rapid, simple and less costly is the ultra-rapid freezing method described for the first time by Rall and Fahy (1985). This procedure, known as a vitrification method, is advantageous compared to the conventional ones in that the embryos become frozen within several minutes and no ice crystals are produced which otherwise are one of the principal causes of cellular damage. It also offers lower osmotic and toxic effects and less dangerous damage during cooling due to rapid transition through the dangerous thermal

Address for correspondence:

MUDr. Radomír Hredzák

2nd Gynaecological-obstetrical clinic

Faculty of Medicine, University of P.J. Šafárik

Rastislavova 43, 04001 Košice, Slovakia

Phone: +421 556153235

Fax: +421556153191

E-mail: hredzak.r@netkosice.sk

http://www.vfu.cz/acta-vet/actavet.htm 
zone. The embryonic suspensions solidify owing to the presence of highly concentrated aqueous solutions of cryoprotectants which, upon cooling, vitrify from the liquid state into a structureless, glassy substance.

The studies involved in comparing the influence of conventional slow-rate freezing and vitrification procedures focused particularly on cleavage of embryos and their implantation capacity. The results are controversial. Some authors claimed that they found no statistical differences between the two methods with regard to the development of blastocysts and their implantation rates for mouse and bovine embryos while others presented better implantation rates with vitrified embryos.

In the present study we decided to compare the effectiveness of slow-rate freezing and vitrification on the basis of development potential of frozen and thawed 2-cell mouse embryos, investigating their capacity to develop in vitro into blastocysts, their morphological characteristics and implantation rates in recipient mice uteri.

\begin{abstract}
Materials and Methods
Embryos

The embryos were obtained from Crj, CD-1 (ICR) mouse line. Female mice were superovulated with 5 IU of pregnant mare serum gonadotrophin (PMGS). The ovulation was induced $48 \mathrm{~h}$ later by 5 IU of human serum choriogonadotrophin (HCG). The successfulness of mating with males was verified by the presence of a vaginal plug. Two-cell embryos were obtained at $44 \mathrm{~h}$ after HCG administration by flushing the oviducts. The embryos were placed in $2 \mathrm{ml}$ of tissue cultivation medium TCM 199 supplemented with $15 \%$ human serum and were cultivated in an atmosphere of $95 \%$ air and $5 \% \mathrm{CO}_{2}$ at $37{ }^{\circ} \mathrm{C}$ for $48 \mathrm{~h}$ to obtain the blastocyst stage. Randomly selected 2-cell embryos were simultaneously frozen by slow-rate freezing method or vitrified. Several days later the embryos were thawed and cultured in the same manner as fresh embryos.
\end{abstract}

Slow-rate freezing and thawing

Two-cell mouse embryos were subjected to slow-rate freezing and thawing according to the method by Las sal et al. (1985). The cryoprotectant used consisted of $1.5 \mathrm{~mol} / 1 \mathrm{propanediol} \mathrm{solution} \mathrm{(Sigma,} \mathrm{St.} \mathrm{Louis,} \mathrm{USA)} \mathrm{in} \mathrm{PBS}$ (phosphate-buffered saline, Gibco, Paisley, Scotland) supplemented with $4 \%$ bovine serum albumin. Prior to freezing the embryos were placed in a $5 \mathrm{M}$ propanediol solution for $15 \mathrm{~min}$ at room temperature. Then they were transferred to a $1.5 \mathrm{M}$ propanediol solution with $0.1 \mathrm{M}$ sucrose (Sigma, St. Louis, USA) and maintained there for additional $15 \mathrm{~min}$ at room temperature. Subsequently, they were loaded in the same solution into $0.25 \mathrm{ml}$ plastic straws for freezing (IMV, L'Aigle, France). The straws were frozen in a programmable freezing apparatus Planer Kryo 10 (Planer Products, Sunbury on Thames, United Kingdom).

The straws were cooled rapidly at the rate of $-2.0^{\circ} \mathrm{C} / \mathrm{min}$ down to $-7.0^{\circ} \mathrm{C}$ when the seeding was performed manually. The straws were then cooled at a rate of $0.3{ }^{\circ} \mathrm{C} / \mathrm{min}$ to $-30{ }^{\circ} \mathrm{C}$ and then at $-50.0^{\circ} \mathrm{C} / \mathrm{min}$ down to $-160.0^{\circ} \mathrm{C}$ and plunged into liquid nitrogen.

Several days later, the embryos were thawed by removing the straws from liquid nitrogen, keeping them at room temperature for $40 \mathrm{~s}$ and then placing them into warm water $\left(30.0^{\circ} \mathrm{C}\right)$ until totally thawed. The cryoprotectant was removed at room temperature by subsequent washing with PBS solutions supplemented with $4 \%$ bovine serum albumin and containing propanediol in decreasing concentrations: $1.0 \mathrm{M}$ propanediol with $0.2 \mathrm{M}$ sucrose, $0.5 \mathrm{M}$ propanediol with $0.2 \mathrm{M}$ sucrose, and $0.2 \mathrm{M}$ sucrose. Finally, sucrose was removed by transferring the embryos into TCM 199.

\title{
Vitrification
}

Vitrification of two-cell mouse embryos was carried out in two stages. In the first stage, the embryos were equilibrated at room temperature for $2 \mathrm{~min}$ in a vitrification solution EFS 20 composed of $20 \%$ ethylene glycol (Fluka Chemica), 18\% Ficoll, 4\% bovine serum albumin, and $0.5 \mathrm{M}$ sucrose in PBS. Then they were transferred to the second vitrification solution EFS 40 containing $40 \%$ ethylene glycol. After exposure for 30-60 s the embryos were loaded to $0.25 \mathrm{ml}$ straws and plunged into liquid nitrogen. After several days of storage, the embryos were thawed by removing them from liquid nitrogen and exposing to the room temperature for $40 \mathrm{~s}$. The cryoprotectant was washed out in three stages: by exposing the embryos to $1 \mathrm{M}$ solution of sucrose in PBS for 5 min, then to $0.5 \mathrm{M}$ solution of sucrose for $5 \mathrm{~min}$ and by rinsing them with PBS solution and transferring into TCM 199 for culturing at $37 \mathrm{oC}$ in an environment consisting of $95 \%$ air and $5 \% \mathrm{CO}_{2}$.

Model of embryonic implantation

In order to ascertain the implantation capacity of investigated embryos 8 blastocysts from each group, i.e. blastocysts cultured in vitro from fresh embryos, from slow-frozen and vitrified embryos, were transferred to the tip of one of the uterine horns in recipient mice on day 3 of medication-induced pseudopregnancy (Morita et al. 1994). On day 9 of gestation, the mice were killed and the ratio of implanted embryos to transferred blastocysts was determined. 
Statistical evaluation

Statistical analysis was carried out using the $\gamma^{2}$-test. Results were evaluated at the $P<0.05$ level.

\section{Results}

After thawing of embryos, normal morphology was observed in 740 out of $911(81.2 \%)$ slow-rate frozen and in 228 out of 295 (77.3\%) vitrified embryos the difference being nonsignificant $(P<0.05)$. The thawed, morphologically intact embryos were allowed to develop in vitro for $48 \mathrm{~h}$ to reach the blastocyst stage. The control group consisted of fresh, two-cell embryos. The number of normal blastocysts which developed from slow-rate frozen embryos $(32.6 \%, 240$ out of 735 embryos) was significantly lower compared to the fresh embryos $(47.6 \%, 245$ out of 515 embryos). The lowest percentage of development to blastocysts was observed in the group of vitrified embryos $(22.3 \%, 48$ out of 215 embryos) and was significantly lower than that in the groups of slow-rate frozen and fresh embryos (Table 1). The morphological appearance of blastocysts cultured in vitro from cryopreserved and fresh embryos was the same.

Table 1. Development rates of blastocysts developed from fresh, slowly frozen and vitrified embryos

\begin{tabular}{|l|c|c|c|}
\hline Blastocysts developed from & No. of thawed embryos & No. of blastocysts & Developmental rate (\%) \\
\hline Fresh 2-cell embryos & 515 & 245 & 47.6 \\
\hline Slowly frozen embryos & 735 & 240 & 32.6 \\
\hline Vitrified embryos & 215 & 48 & $22.3^{\text {a,b }}$ \\
\hline
\end{tabular}

a $P<0.001$ compared with development rates of fresh embryos

${ }^{\mathrm{b}} P<0.05$ compared with development rate of slowly frozen embryos

The highest implantation rates were observed with blastocysts which developed in vitro from fresh two-cell embryos that were transferred to recipient mice. Of 134 transferred embryos 42 were implanted successfully (31.3\%) (Table 2). The implantation rate of blastocysts developed from slow-rate frozen embryos was lower compared to that observed in fresh embryos but the difference was insignificant. On the other hand, significantly lower implantation rates were observed for blastocysts which developed in vitro from vitrified embryos (Table 2).

Table 2. Implantation rates of blastocysts developed in vitro from fresh 2-cell embryos and from frozen embryos

\begin{tabular}{|l|c|c|c|}
\hline $\begin{array}{l}\text { Blastocysts developed } \\
\text { from }\end{array}$ & $\begin{array}{c}\text { No. of transferred } \\
\text { blastocysts }\end{array}$ & $\begin{array}{c}\text { No. of implanted } \\
\text { blastocysts }\end{array}$ & Implantation rate (\%) \\
\hline Fresh 2-cell embryos & 134 & 42 & 31.3 \\
\hline Slowly frozen embryos & 76 & 16 & 21.1 \\
\hline Vitrified embryos & 99 & 11 & $11.1^{\mathrm{a}, \mathrm{b}}$ \\
\hline
\end{tabular}

a $P<0.001$ compared with implantation rates of blastocysts developed in vitro from fresh embryos.

${ }^{\mathrm{b}} P<0.05$ compared with implantation rates of blastocysts developed from slowly frozen embryos

\section{Discussion}

There is a difference in the development of fresh and frozen embryos as indicated by our results and other publications (Selick et al. 1995; Uechi et al. 1997). Our study showed that the development rates of blastocysts for vitrified two-cell embryos after 48-h culturing were significantly lower in comparison with fresh and slow-rate frozen embryos. This indicates that freezing of early embryos affects negatively their further development and one can expect that vitrification, although simpler and more rapid than the slow-rate freezing, causes more damage to embryos. 
The information published on the influence of vitrification of early embryos differs and a number of authors reported good results with vitrification. Our results could be influenced by several factors: the mouse line, the developmental stage at which mouse embryos undergo cryopreservation and the cooling rate which is affected particularly by the freezing carrier system (container) in which the embryos are held (in our case $0.25 \mathrm{ml}$ straws, commonly used in slow-rate freezing).

We used the inbred line of mice Crj, CD-1 (ICR) with relatively low development potential of two-cell embryos. Only approximately $50 \%$ of them developed in vitro into the blastocyst stage. Other authors reached better results with $\mathrm{B} 6 \mathrm{C} 3 \mathrm{~F} 1$ hybrid mouse lines (Ishida et al. 1997). Some authors reported better survival of later stages of vitrified embryos (eight-cell or morula) (Mukaida et al. 1998). The reason why we used two-cell mouse embryos was that they correspond best to human four- and eight-cell embryos with regard to the morphology and size of blastomers. Moreover we assumed that any difference in the detrimental effect between the two cryopreservation methods may become more manifest if a "suboptimal" line of mice in a "suboptimal" development stage is used. We hope that our data obtained in two-cell embryos of ICR mice will help to improve the freezing protocols for human embryos which frequently do not have optimal quality.

The viability of embryos from all investigated groups was evaluated by means of the model of implantation of embryos into uteri of recipient mice. The implantation rates of blastocysts which developed in vitro from vitrified two-cell embryos were significantly lower in comparison with blastocysts obtained from fresh and slow-rate frozen embryos. The above mentioned indicates that the quality of blastocysts developing from vitrified embryos is lower and their capacity for implantation is reduced although they are morphologically identical with those developed from slow-rate frozen embryos.

Important factors affecting successfulness of vitrification include temperature decrease rates and cooling of vitrification solutions. An important role in the solution cooling rates is ascribed to the freezing container, thermal conductivity of its walls and the volume of vitrification solution (Liebermann et al. 2003). We recognise several carrier systems (containers) into which the embryos in a cryoprotectant solution are loaded: open pulled straw (Chen et al. 2000), electron microscopic copper grid (S on et al. 2003), hemi-straw system (Liebermann 2002), and cryoloop (Reed et al. 2002). A disadvantage of the majority of these systems is that during the procedure the vitrification solution comes to direct contact with liquid nitrogen which can become a source of its contamination. We used conventional $0.25 \mathrm{ml}$ straws which are commonly employed in slow-rate freezing and isolate the embryos from their surroundings. It seems that this very isolation, relatively thick walls of the straw and large volume of vitrification solution are the factors which decrease the cooling rates and reduce survival of embryos after thawing. It is therefore necessary to look further for an optimum system of storage of embryos during vitrification.

In conclusion, a "universal" vitrification protocol does not exist as yet. The authors who published papers on this subject used various vitrification solutions and different containers for holding the embryos which may explain the disparity of results. The container used in our study is advantageous as it isolates embryos from their surroundings and minimises the risk their contamination but, on the other hand, decreases the cooling rates. Additional empirical studies are needed to optimise the vitrification protocols.

\section{Vplyv pomalého zmrazovania a vitrifikácie na myšacie embryá}

Cielom štúdie bolo porovnat vplyv dvoch metód zmrazovania embryí (pomalé zmrazovanie pomocou programovatelného zmrazovacieho prístroja a ultrarýchle zmrazenie metódou vitrifikácie) na vývojovú schopnosṫ dvojbunkových myšacích embryí, na základe ich vývoja in vitro do štádia blastocysty a implantačnej schopnosti blastocýst. Dvojbunkové 
embryá boli získané zo superovulovaných myšacích samíc a rozdelené do troch skupín. Jedna skupina embryí bola zmrazená metódou pomalého zmrazovania v programovatelnom zmrazovacom prístroji, ako kryoprotektívum bol použití propándiol. Druhá skupina bola zmrazená metódou vitrifikácie, ako kryoprotektívum bol použitý etylénglykol. Tretia skupina embryí bola bez zmrazenia kultivovaná in vitro v kultivačnom médiu v prostredí $95 \%$ vzduch a $5 \% \mathrm{CO}_{2}$. Po rozmrazení boli embryá oboch skupín kultivované in vitro za rovnakých podmienok ako čerstvé embryá. Čast̉ blastocýst vyvinutých in vitro z embryí všetkých troch skupín bola prenesená do maternice pseudogravidných myšacích samíc, za účelom zistenia ich implantačnej schopnosti. Percento vitrifikovaných embryí, ktoré sa vyvíjali do štádia blastocysty bolo signifikantne menšie ako u čerstvých embryí a embryí pomaly zmrazených. Morfologický vzhlad embryí zo všetkých troch skupín bol rovnaký. Frekvencia implantácie blastocýst vzniknutých z vitrifikovaných embryí bola signifikantne nižšia ako u čerstvých a pomaly zmrazených embryí. Tieto výsledky ukazujú, že zmrazovanie embryí má negatívny vplyv na ich další vývoj a tento je výraznejší pri vitrifikácii. Ked’že neexistuje „univerzálny“ protokol vitrifikácie, sú potrebné dalšie štúdie za účelom jej optimalizácie.

\section{Acknowledgements}

The study was supported by the Project VEGA M· SR, No. 1/8298/01.

\section{References}

CHEN SU, LIEN YR, CHEN HF CHAO KH, HO HN, YANG YS 2000: Open pulled straws for vitrification of mature mouse oocytes preserve patterns of meiotic spindles and chromosomes better than conventional straws. Hum Reprod 15: 2598-2603

ISHIDA GM, SAITO H, OHTA N, TAKAHASI T, ITO MM, SAITO T, NAKAHARA K, HIROI M 1997: The optimal equilibration time for mouse embryos frozen by vitrification with trehalose. Hum Reprod 12: 1259-1262

LASSALE B, TESTART J, RENARD JP 1985: Human embryo features that influence the succes of cryopreservation with the use of 1,2 propanediol. Fertil Steril 44: 654-651

LIEBERMANN J, DIETL J, VANDERZWALMEN P et al. 2003: Recent developments in human oocyte, embryo and blastocyst vitrification: where are we now? Reproductive BioMedicine Online 7: 623-633

LIEBERMANN J, TUCKER MJ 2002: Effect of carrier system on the yield of human oocytes and embryos as assessed by survival and developmental potential after vitrification. Reproduction 124: 483-489

MORITA Y, TSUTSUMI O, TAKETAMI Z 1994: In vitro treatment of embryos with epidermal growth factor improves viability and increases the implantation rate of blastocyst transferred to recipient mice. Am J Obstet Gynecol 171: 406-409

MUKAIDA T, WADA S, TAKAHASHI K PEDRO PB, AN TZ, KASAI M 1998: Vitrification of human embryos based on the assessment of suitable conditions for 8-cell mouse embryos. Hum Reprod 13: 2874-2879

RALL WF, FAHY GM 1985: Ice-free cryopreservation of mouse embryos at -196 degrees C by vitrification. Nature 313: 573-575

REED ML, LANE M, GARDNER DK, JENSEN NL, THOMPSON J 2002: Vitrification of human blastocysts using the cryoloop method: successful clinical application and birth of offspring. J Assist Reprod Gen 19: 304-306

SELICK CE, HOFMANN GE, ALBANO C HOROWITZ GM, COPPERMAN AB, GARRISI GJ, NAVOT D 1995: Embryo quality and pregnancy potential of fresch compared with frozen embryos - is freezing detrimental to high quality embryos? Hum Reprod 10: 392-395

SON WY, YOON SH, YOON HJ, LEE SM, LIM JH 2003: Pregnancy outcome following transfer of human blastocysts vitrified on electron microscopy grids after colapse of the blastocoele. Hum Reprod 18: 137-139

UECHI H, TSUTSUMI O, TAKETANI Y 1997: Cryopreservation of mouse embryos affects later embryonic development possibly through reduced expression of the glucose transporter GLUT1. Mol Reprod Dev 48: 496-500 